\title{
Effects of Some Monetary Policy Targets on Inflation and Inflation Volatility: Evidence from Nigeria
}

\author{
Amaefula C. G \\ Department of Mathematics and Statistics, Federal University Otuoke, Bayelsa State, Nigeria
}

\begin{abstract}
The persistent inflationary pressure despite monetary policy targets has become a phenomenon of interest among researchers. The study investigates the effects of monetary policy targets on inflation and its volatility in Nigeria using data spanning from 1985 to 2019. The ADF unit root test used confirmed that all the variables under study are integrated order zero in their level series. A Comparison of inflation volatility models (ARCH and GARCH models) with appropriate error distribution using AIC indicated that ARCH (1) is most appropriate. The results of least squares (LS) and maximum likelihood (ML) ARCH methods of estimation for the model specifications showed that measures of monetary policy targets such as narrow money supply (M1), broad money supply (M2), net domestic credit(NDC), net credit to government(NCG) and credit to private sector(CPS) have no significant effect on inflation and inflation volatility respectively except M2. However, M2 effect spurs inflation rather than curbing it. Hence, it becomes imperative for the government to make proactive policies targeted to reduce inflationary pressures so as to attain price stability in Nigeria's economic space.
\end{abstract}

Keywords: monetary policy targets, inflation, Volatility models

\section{INTRODUCTION}

The rising inflationary pressure which has necessitated consistent increase in the prices of goods and services in Nigeria has become a phenomenon of concern to doubt if monetary policies targeted at inflation by the Monetary Policy
Committee (MPC) are actually curbing inflationary pressure. In order to deal with the causal factors of inflation in Nigeria, there is the urgent need to have empirical evidence relating the rising inflation to either monetary or nonmonetary factors. The recent economic recession couple with rising inflation (observable from rising domestic prices) in Nigeria spurred the need for the present study, as this will help the monetary policy makers to take necessary actions the will combat the inflationary pressure and restore price stability within Nigeria's economic space.

There is this general conformity among economists that inflation rate is essentially dependent on the growth rate of money supply in the long-run. And, in the short and medium term inflation tends to be affected by supply and demand pressures in the economy, and influenced by the relative elasticity of wages, prices and interest. In many economists view, prices and wages adjust at different rates, and these differences have enough effects on real output to be "large period" in the view of person in an economy.

Some earlier studies have shown that inflation uncertainty have positive relationship with interest rate. Many researchers like ${ }^{[13]}$; ${ }^{[18]}$; ${ }^{[12]}$ and ${ }^{[9]}$ have provided empirical evidence for the positive relationship between expected inflation variation and the t-bill rates under different specifications such as asset pricing models. ${ }^{[14]}$ have confirmed a relationship between 
interest rate and inflation rate in the longrun.

The dynamic relationship between short term interest rates and inflation was investigated for the US, the UK, France, Germany, and Switzerland for the period 1974-1980. The result strongly suggests the variation of the nominal interest rate and inflation help to predict the ex ante real interest rate ${ }^{\text {[17] }}$. The effect of inflation and uncertainty on interest rates in the UK with quarterly data from 1958:4 to $1994: 4$ was studied and the result showed that both expected inflation and conditional variability of inflation positively affect the UK three-month treasury- bill rate ${ }^{[6]}$.

${ }^{[20]}$ incorporated inflation, output gap and nominal interest rate regarding monetary policy according to Taylor's rule and suggested a realistic model of output gap that may be quite different from theoretical measures which should be based on interest rate. ${ }^{[5]}$ applied VAR model and found the optimization problem regarding adjusting policy rates at central banks by the policymakers and also suggested that Taylor rule must be incorporated with the macroeconomic models to forecast the economy.

The interaction between nominal interest rates and inflation was examined for for Turkey over the period of 1984-2003 and the result supports the idea that there is a long-run relationship between interest rates and inflation for Turkish markets, and causality exists in only one direction from nominal interest rates to inflation ${ }^{[15]}$. ${ }^{[16]}$ employed a VEC model to examine the relationship between inflation and interest rates for 114 economies over a 45 year period using monthly data. Interest rates and inflation are found to exhibit a long-run equilibrium relationship for numerous economic states. However, in states with large positive changes of inflation, high inflation risk or high interest rates, a longrun equilibrium relationship may not exist.

[19] examined the relationship between inflationary expectations and the variations in interest rate in Nigeria using the Generalized Method of Moment (GMM) estimator and their result indicated that the effect of interest rate variation on expected inflation in Nigeria is negative and significant. [2] investigated the effects of inflation and its risk on interest rate in Nigeria. $\operatorname{ARCH}(1)$ and $\operatorname{GARCH}(1,1)$ were used to measure inflation risk and the result indicated that $\operatorname{GARCH}(1,1)$ measured inflation risk better than $\mathrm{ARCH}(1)$ model based on Schwarz Information Criterion (SIC), and adopting multiple regression method, the result reveals that inflation and inflation risk exact negative and positive impacts on interest rate respectively, but none is significant. This result implies that the direction of monetary policy rate (MPR) is not proactive enough to curb the rising inflationary pressure in Nigeria. [3] also examines whether long-run equilibrium relationship exist between interest rate and inflation in Nigeria, using frame work of Johansen cointegration test vector error correction model (VECM) of granger causality test and his results show evidence of long-run equilibrium relationship between the two variables with strong evidence of unidirectional granger causality flow from interest rate to inflation at the long-run.

The effect of monetary policy on inflation in Nigeria was studied with a data sets covering the period of $2006 \mathrm{M} 1$ to 2017M4. The results of the generalized linear models (GLM) specified showed that three months deposit rate(IIIMDR) exacts right directional (negative) effect on inflation, significant at $10 \%$ level while ), twelve months deposit rate(XIIMDR) and prime lending rate(PLR) have positive (unexpected directional effect) on inflation, significant at $1 \%$ and $5 \%$ respectively. Treasury bill rate(TBR) at lag 2 exacts right directional (negative) effect on current inflation significant at $1 \%$ level. It is observed that among all the predictors considered in this study, three months' deposit rate has direct effect in controlling inflation towards the right direction while treasury bill rate influences inflation toward 
the right direction in shot-run ${ }^{[4]} .{ }^{[1]}$ studied the relationship between interest rates and inflation in Ghana and their impact on economic growth for the period 2006-2019. The result showed that interest rates and inflation rates in Ghana were positively correlated and they had strong impact on the economic growth of Ghana within the period under review. The researcher, however, observed that the coefficient of correlation between interest rates and inflation rates from 2006-2015 was stronger than from 2016-2019.

Previous studies have concentrated on the effects of monetary policy rates on inflation. The essence of the study is to examine how proactive some monetary policy targets curb inflation and its volatility in Nigeria. The study also investigates the effects of previous inflation together with some monetary targets on current inflation and its volatility.

The rest part of the paper is organized as follows; section 2 presents the material and methods, section 3 deals with the data analysis and results, and section 4 presents the conclusion.

\section{MATERIALS AND METHODS}

This research is descriptive in nature and the data is quantitative in nature. Only the secondary data were used. Time sample data were collected from the world development indicators report, internal database and websites from 1972-2016.

This section provides information on source of data collection, variable measurement and definition, Volatility model specification, method of estimation, method of unit root tests, and diagnostic test

\subsection{Source of Data Collection}

The data sets on narrow money supply (M1), broad money supply(M2), net domestic credit(NDC), Net credit to government(NCG), credit to private sector(CPS) and inflation (INF) were obtained from published Central Bank of Nigeria ${ }^{[8]}$ statistical bulletin as compiled by Debt Management Office and Central bank of Nigeria. The yearly time series data sets cover the period of 1985 to 2019.

\subsection{Variable Measurement and Definition}

This paper uses narrow money supply (M1), broad money supply (M2), net domestic credit (NDC), net credit to government (NCG), credit to private sector (CPS) are measures of monetary policy target.

\subsection{Conditional Heteroskedasticity Model}

Moreover, since inflation risk is not directly observable, the better describing Conditional Heteroskedasticity model between Autoregressive Conditional Heteroskedasticity (ARCH (1)) Model and Generalized ARCH $(1,1)$ model were adopted to measure inflation risk. In other words, inflation risk is measured using inflation volatility (conditional variance).

According to ${ }^{[11]}$ given the mean equation of inflation asinf ${ }_{t}=\mu+\varepsilon_{t}$, the $\mathrm{ARCH}(\mathrm{p})$ is of the form;

$\sigma_{t}^{2}=\alpha_{0}+\sum_{i=1}^{p} \alpha_{1 i} \varepsilon_{t-i}^{2}$

were the nonnegativeness and stationarity of $\sigma_{t}^{2}$ are guaranteed for $\alpha_{0}>0$ and $0 \leq \alpha_{i}<1$ - Hence, $\sigma_{t}^{2}$ becomes a function of the previous squared shock, large shocks of either sign tend to be preceded by large shock and vice versa. Though the ARCH (1) model can capture the stylized facts of volatility clustering and excess kurtosis, its short coming is that, it is unlikely that the model accommodates for the features related to the autocorrelation function of squared disturbances $\varepsilon_{t}^{2}$. And according ${ }^{[7]}$ $\operatorname{GARCH}(1,1)$ is of the form;

$$
\sigma_{t}^{2}=\alpha_{0}+\sum_{i=1}^{p} \alpha_{1 i} \varepsilon_{t-i}^{2}+\sum_{j=1}^{q} \alpha_{2 j} \sigma_{t-j}^{2}
$$

where $\varepsilon_{t} \rightarrow t\left(o, \sigma^{2}, v\right)$, the tail parameter $v>2$ and t-distribution approaches normal distribution if $v \rightarrow \infty$. According to the property of GARCH model, $0 \leq \alpha_{1 i}, \alpha_{2 j} \leq 1$ 
Amaefula $C$. G. Effects of some monetary policy targets on inflation and inflation volatility: evidence from Nigeria.

and $\left(\alpha_{1 i}+\alpha_{2 j}\right)<1$ show that the model is covariance stationary. For instant, a large $\varepsilon_{t-1}^{2}$ or $\sigma_{t-1}^{2}$ gives rise to a large $\sigma_{t}^{2}$. This means that a large $\varepsilon_{t-1}^{2}$ tends to be followed by another large $\varepsilon_{t}^{2}$, generating again, the well-known behavior of volatility clustering in financial time series. Note that $\varepsilon_{t-1}^{2}$ (ARCH term) represents news concerning volatility from the previous period, which is measured as the lag of the squared residual from the mean equation and $\sigma_{t-1}^{2}(\mathrm{GARCH}$ term) represents the last period's forecast variance.

Note that the appropriate lag of the conditional variance will be selected on the basis of Akaike information criterion

\subsection{Unit Root Test}

The unit root test here, is based on Augmented Dickey Fuller (ADF) test and it is of the form

$$
\begin{aligned}
\nabla y_{t}=\alpha+\alpha_{1} t & +\beta y_{t-1} \\
& +\sum_{i=1}^{k} \xi_{i} \nabla y_{t-i}+a_{t}
\end{aligned}
$$

where $\mathrm{k}$ is the number of lag variables. In (3) there is intercept term, the drift term and the deterministic trend. ADF unit root test null hypothesis $H_{0}: \beta=0$ and alternative $H_{a}: \beta<0$. According to ${ }^{[10]}$, if the $\mathrm{ADF}$ test statistic is greater than $1 \%, 5 \%$ and $10 \%$ critical values, the null hypothesis of a unit root test is accepted.

\subsection{Regression Model Specification}

The multiple regression specification is necessary to examine the effects of the monetary policy targets $(\mathrm{m} 1, \mathrm{~m} 2$, ndc, ncg, and cps) on inflation.

inf $f_{t}=\beta_{0}+\beta_{1} i n f_{t-1}+\beta_{2} m 1_{t}+$ $\beta_{3} m 2_{t}+\beta_{4} n d c_{t}+\beta_{5} n c g_{t}+\beta_{6} c p s_{t}+e_{t 1}$ (4) where $\quad \beta_{i}(i=0,1,2,3,4,5$ and 6$) \quad$ are regression coefficients. The error term $e_{t 1}$ is expected to be normally distributed with mean zero (0) and variance $\sigma^{2}$. The $\beta_{1}$ becomes the coefficient of Inflation at time $t-1$ (previous year inflation).

The model specification for the effects of monetary policy targets $(\mathrm{m} 1, \mathrm{~m} 2$, ndc, ncg, and cps) on Inflation volatility is given as follows

$\sigma_{i n f, t}^{2}=\beta_{0}+\beta_{1} \varepsilon_{t-1}^{2}+\beta_{2} \sigma_{t-1}^{2}+$ $\beta_{3} m 1_{t}+\beta_{4} m 2_{t}+\beta_{5} n d c_{t}+\beta_{6} n c g_{t}+$ $\beta_{7}$ cps $_{t}$

where $\sigma_{\mathrm{inf}, t}^{2}$ is the conditional variance of inflation and $\beta_{i}=(1=0,1, \cdots, 7)$ are the parameter coefficients.

\subsection{Method of Estimation}

The coefficients of the ARCH/GARCH models are estimated by the method of maximum likelihood under the assumption that the model errors are conditionally normally distributed.

\section{DATA ANALYSIS AND RESULTS}

This chapter presents the pictorial representation, unit root test, conditional volatility model comparison and estimation, regression analysis and some diagnostic tests. The specified regression model is estimated using generalized least square method.

\subsection{Graphical Representation of the Variables}

In this section, the time series plot of inflation(INF), narrow money supply (M1), broad money supply(M2), net domestic credit(NDC), Net credit to government(NCG), credit to private sector(CPS) are presented below 
Amaefula $C$. G. Effects of some monetary policy targets on inflation and inflation volatility: evidence from Nigeria.

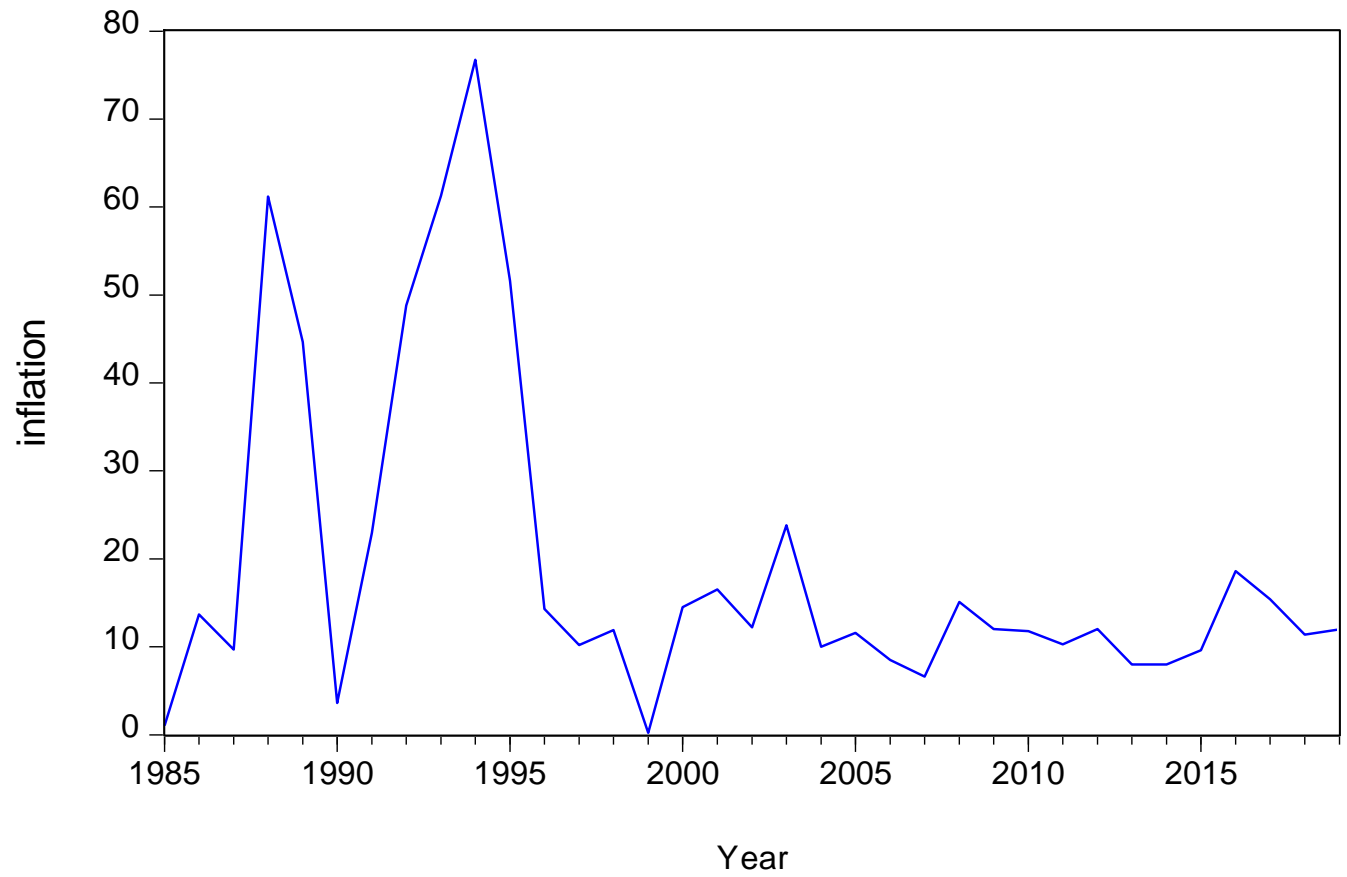

Figure1. Time series plot of actual inflation (1985 - 2019)

The plot in Figure1 exhibits more inflation value occurred in 1999 and highest variation in the first half of the series than in peak in 1995 for the period under study. the second half of the series. The lowest

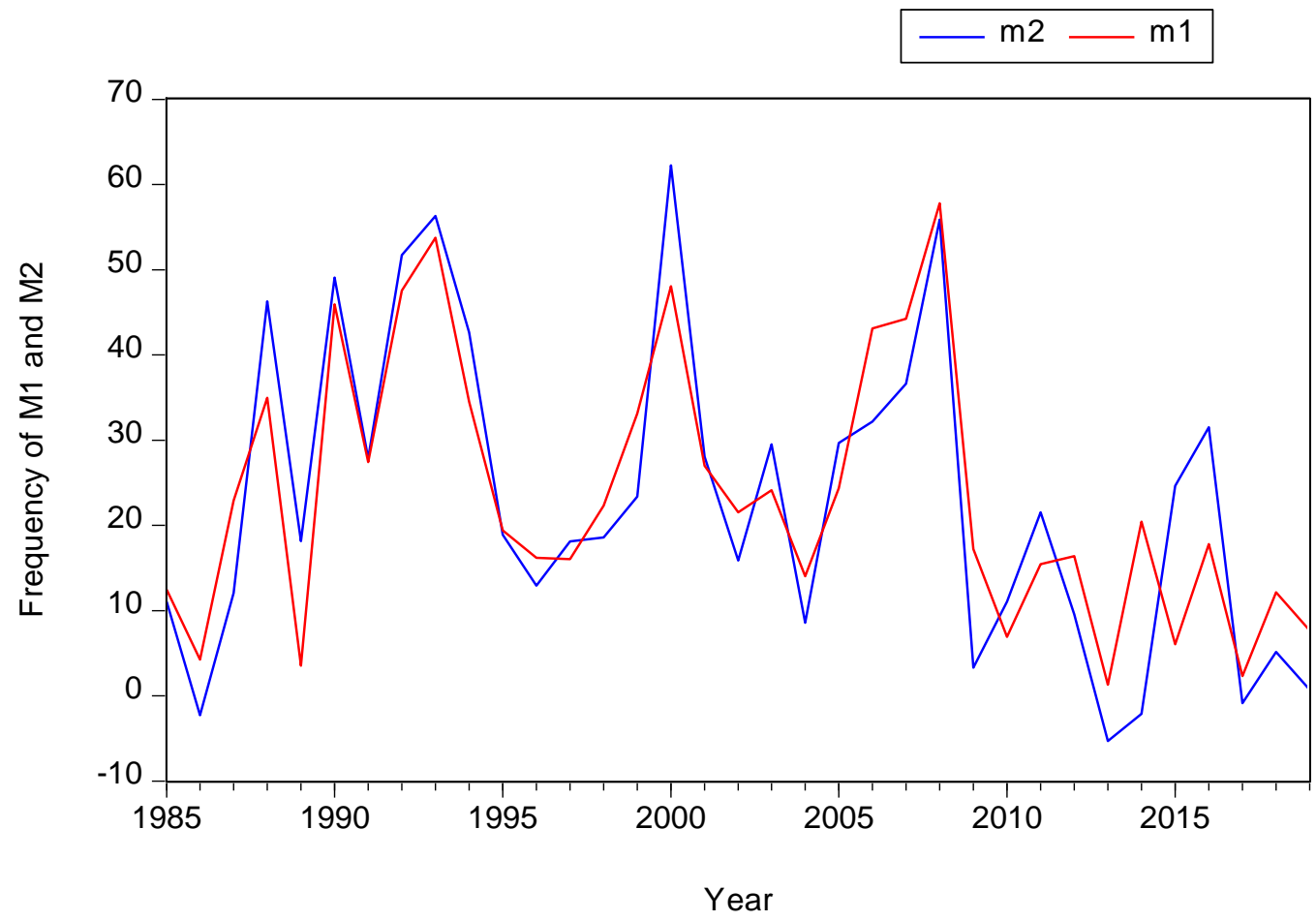

Figure2. Time series plot of M1 and M2 (1981 - 2019)

Narrow money supply (M1) and broad money supply (M2) in Figure 2 are very close in their distribution and tend to slowly trend downwards. 
Amaefula $C$. G. Effects of some monetary policy targets on inflation and inflation volatility: evidence from Nigeria.

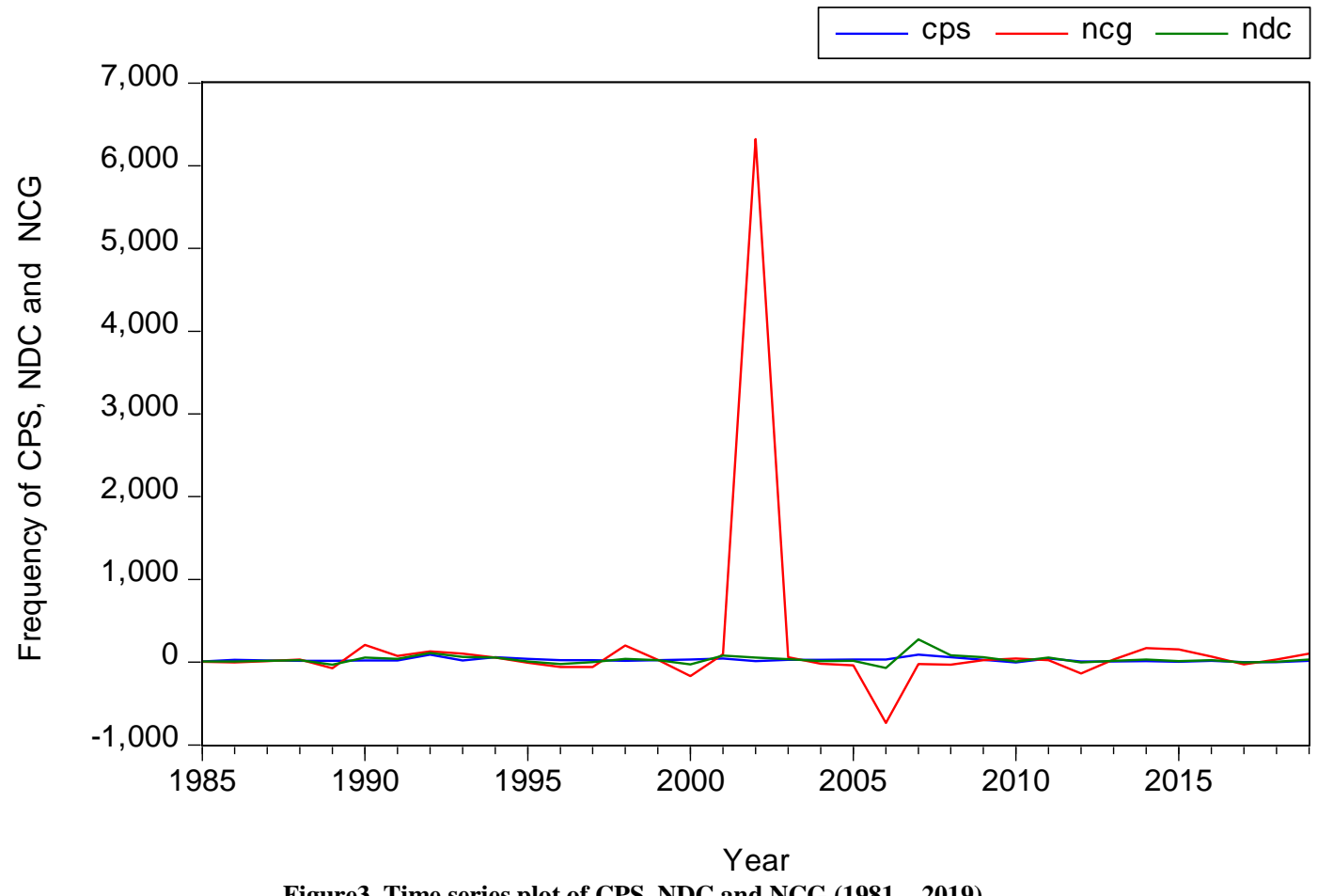

Apart from 2003 where NCG showed a peak outside zero, the net domestic credit (NDC), net credit to government(NCG) and credit to private sector(CPS) in Figure 3 exhibit fluctuation around zero

\subsection{Result of ADF Unit Root Test}

The result of ADF unit root test of the variables under investigation is summarized below;

\begin{tabular}{|c|c|c|c|c|c|c|c|}
\hline Test & Series & $\begin{array}{l}\text { Deter- } \\
\text { ministic } \\
\text { Term }(D T)\end{array}$ & $\begin{array}{l}\text { Lags/ } \\
\text { Band- } \\
\text { width }\end{array}$ & $\begin{array}{l}\text { Test } \\
\text { Value }\end{array}$ & $\begin{array}{l}1 \% \text { level } \\
5 \% \text { level } \\
10 \% \text { level }\end{array}$ & Prob. & Remark \\
\hline \multirow{6}{*}{$\mathrm{ADF}$} & inf & $\mathrm{C}, \mathrm{T}$ & 6 & -3.2621 & $\begin{array}{l}-4.3240 \\
-3.5806 \\
-3.2253\end{array}$ & 0.0934 & $\begin{array}{l}\text { Stationary } \\
\text { at } 10 \% \text { level }\end{array}$ \\
\hline & cps & $\mathrm{C}, \mathrm{T}$ & 0 & -4.8343 & $\begin{array}{l}-4.2529 \\
-3.5484 \\
-3.2071\end{array}$ & 0.0023 & $\begin{array}{l}\text { Stationary } \\
\text { under } 5 \% \text { level }\end{array}$ \\
\hline & $m 1$ & $\mathrm{C}, \mathrm{T}$ & 0 & -3.9858 & $\begin{array}{l}-4.2529 \\
-3.5484 \\
-3.2071\end{array}$ & 0.0189 & $\begin{array}{l}\text { Stationary } \\
\text { at } 5 \% \text { level }\end{array}$ \\
\hline & $m 2$ & $\mathrm{C}, \mathrm{T}$ & 0 & -4.3538 & $\begin{array}{l}-4.2529 \\
-3.5484 \\
-3.2071\end{array}$ & 0.0078 & $\begin{array}{l}\text { Stationary } \\
\text { under } 5 \% \text { level }\end{array}$ \\
\hline & $n c g$ & $\mathrm{C}, \mathrm{T}$ & 0 & -5.5995 & $\begin{array}{l}-4.2529 \\
-3.5484 \\
-3.2071\end{array}$ & 0.0003 & $\begin{array}{l}\text { Stationary } \\
\text { under } 5 \% \text { level }\end{array}$ \\
\hline & $n d c$ & $\mathrm{C}, \mathrm{T}$ & 0 & -5.7676 & $\begin{array}{l}-4.2529 \\
-3.5484 \\
-3.2071\end{array}$ & 0.0002 & $\begin{array}{l}\text { Stationary } \\
\text { under } 5 \% \text { level }\end{array}$ \\
\hline
\end{tabular}

The unit root test in Table1 indicates that the variables under investigation are all stationary under their level series and all are significant under 5\% level, except inflation that is significant under $10 \%$ level.

\subsection{Comparison of Conditional Heteroskedasticity Model}

In this section, the AIC model selection criterion will be used to select the best describing ARCH/GARCH model for 
Amaefula $C$. G. Effects of some monetary policy targets on inflation and inflation volatility: evidence from Nigeria.

measuring the volatility of inflation and the result is presented in Table 2 below;

Table 2. Comparing ARCH/GARCH Models with Apposite Error Distribution using AIC

\begin{tabular}{|l|l|l|l|l|}
\hline Error Distribution & Model & AIC & SIC & Remark \\
\hline Normal & ARCH(1) & 8.3720 & 8.5053 & No heteroskedasticity in the model residuals up to lag 3 \\
\cline { 2 - 5 } & GARCH(1,1) & $7.9879 *$ & 8.1656 & No heteroskedasticity in the model residuals up to lag 4 \\
\cline { 2 - 5 } & GARCH(2,1) & 8.1514 & 8.3735 & No heteroskedasticity in the model residuals up to lag 4 \\
\cline { 2 - 5 } & GARCH(1,2) & 8.0230 & 8.2452 & No heteroskedasticity in the model residuals up to lag 4 \\
\hline Student's t & ARCH(1) & 7.5937 & 7.7715 & No heteroskedasticity in the model residuals up to lag 3 \\
\cline { 2 - 5 } & GARCH(1,1) & 7.7098 & 7.9320 & No heteroskedasticity in the model residuals up to lag 3 \\
\cline { 2 - 5 } & GARCH(2,1) & Singular co-variance coefficients \\
\cline { 2 - 5 } & GARCH(1,2) & 7.7208 & 7.9874 & No heteroskedasticity in the model residuals up to lag 3 \\
\hline GED & ARCH(1) & 7.4072 & 7.5849 & No heteroskedasticity in the model residuals up to lag 3 \\
\cline { 2 - 5 } & GARCH(1,1) & 7.4557 & 7.6779 & No heteroskedasticity in the model residuals up to lag 15 \\
\cline { 2 - 5 } & GARCH(2,1) & 7.5086 & 7.7752 & No heteroskedasticity in the model residuals up to lag 15 \\
\cline { 2 - 5 } & GARCH(1,2) & 7.4976 & 7.7642 & No heteroskedasticity in the model residuals up to lag 15 \\
\hline & \multicolumn{3}{|c}{ The symbol (*) indicates the smallest value of AIC }
\end{tabular}

The analysis in Table 2 above indicates that comparing ARCH/GARCH models with appropriate error distribution, AIC chose the generalize error distribution (GED) and ARCH(1) has the smallest value of AIC, hence, it is selected as the best conditional heteroskedasticity measure of inflation volatility. For the mean equation $\inf _{t}=12.0+e_{t}$, the $\operatorname{ARCH}(1)$ model is of the form;

$$
\begin{aligned}
& \sigma_{t}^{2}=124.0055+4.7918 \varepsilon_{t-i}^{2} \\
& p-\text { val. }(0.4171)(0.5712)
\end{aligned}
$$

The volatility model in (6) indicates that $\varepsilon_{t-1}^{2}$ (news about volatility from the previous period) has no significant effect on current volatility.

\subsection{Result of Regression Model}

The result of the regression model on the effect of monetary policy target on inflation is presented in Table 4 below;

\begin{tabular}{|c|c|c|c|c|}
\hline \multicolumn{5}{|c|}{ Dependent Variable: INF } \\
\hline \multicolumn{5}{|c|}{ Method: Least Squares } \\
\hline \multicolumn{5}{|c|}{ Sample (adjusted): 19862019} \\
\hline \multicolumn{5}{|c|}{ Included observations: 34 after adjustments } \\
\hline Variable & Coefficient & Std. Error & t-Statistic & Prob. \\
\hline $\mathrm{C}$ & 3.103598 & 5.305692 & 0.584956 & 0.5634 \\
\hline $\inf (-1)$ & 0.521053 & 0.137345 & 3.793744 & 0.0008 \\
\hline cps & 0.096892 & 0.185783 & 0.521534 & 0.6062 \\
\hline ndc & -0.003304 & 0.065089 & -0.050766 & 0.9599 \\
\hline $\mathrm{m} 1$ & -0.457889 & 0.354435 & -1.291885 & 0.2073 \\
\hline $\mathrm{m} 2$ & 0.647187 & 0.282114 & 2.294063 & 0.0298 \\
\hline ncg & $3.63 \mathrm{E}-05$ & 0.002399 & 0.015116 & 0.9881 \\
\hline R-squared & 0.526400 & \multicolumn{2}{|c|}{ Mean dependent var } & 19.96417 \\
\hline Adjusted R-squared & 0.421156 & \multicolumn{2}{|c|}{ S.D. dependent var } & 18.69839 \\
\hline S.E. of regression & 14.22607 & \multicolumn{2}{|c|}{ Akaike info criterion } & 8.329271 \\
\hline Sum squared resid & 5464.292 & \multicolumn{2}{|c|}{ Schwarz criterion } & 8.643522 \\
\hline Log likelihood & -134.5976 & \multicolumn{2}{|c|}{ Hannan-Quinn criter. } & 8.436440 \\
\hline F-statistic & 5.001690 & \multicolumn{2}{|c|}{ Durbin-Watson stat } & 1.646420 \\
\hline Prob(F-statistic) & 0.001462 & & & \\
\hline
\end{tabular}

Table 4. Regression Estimates of Equation (4)

The regression result in Table 4 shows that the monetary policy target variables (narrow money supply (M1), broad money supply(M2), net domestic credit (NDC), net credit to government(NCG) and credit to private sector (CPS) ) have no significant effect on inflation except that of $\mathrm{M} 2$ and it is significant at 5\% level. The result also showed that the previous year inflation has positive impact on present inflation and it is significant at $1 \%$ level. The $\mathrm{R}^{2}$ indicates that $52.6 \%$ variation in inflation is accounted by Nigeria's NDC, CPS, M1, M2 and NCG and previous year actual inflation. The Fstatistic is significant under $1 \%$ level, showing the existence of linear relationship between the explanatory variables and 
Amaefula $C$. G. Effects of some monetary policy targets on inflation and inflation volatility: evidence from Nigeria.

inflation in Nigeria. But Durbin-Watson statistic is getting closer to 2, however, indicating presence of serial correlation in the residual and a further test of serial correlation will be done using BreuschGodfrey Serial Correlation LM Test and the result is presented in Table 5 below.

Table 5. Serial Correlation Test for the Estimated Regression model

\begin{tabular}{|l|c|c|c|}
\hline \multicolumn{1}{|c|}{ Breusch-Godfrey Serial Correlation LM Test: } & \\
\hline F-statistic & 1.630344 & Prob. F(2,25) & 0.2160 \\
\hline Obs*R-squared & 3.922884 & Prob. Chi-Square(2) & 0.1407 \\
\hline
\end{tabular}

Breusch-Godfrey Serial Correlation LM Test in Table5 indicates absence of serial correlation in the residuals of the regression model up to lag 2 .

\begin{tabular}{|l|l|l|l|}
\hline \multicolumn{2}{|c|}{ Table 6. Heteroskedasticity Test: Breusch-Pagan-Godfrey } \\
\hline F-statistic & 2.453045 & Prob. F(6,27) & 0.0505 \\
\hline Obs*R-squared & 11.99525 & Prob. Chi-Square(6) & 0.0621 \\
\hline
\end{tabular}

The result in Table6, shows there is no heteroskedasticity in the model residuals as the p-values are not significant under 5\% level.

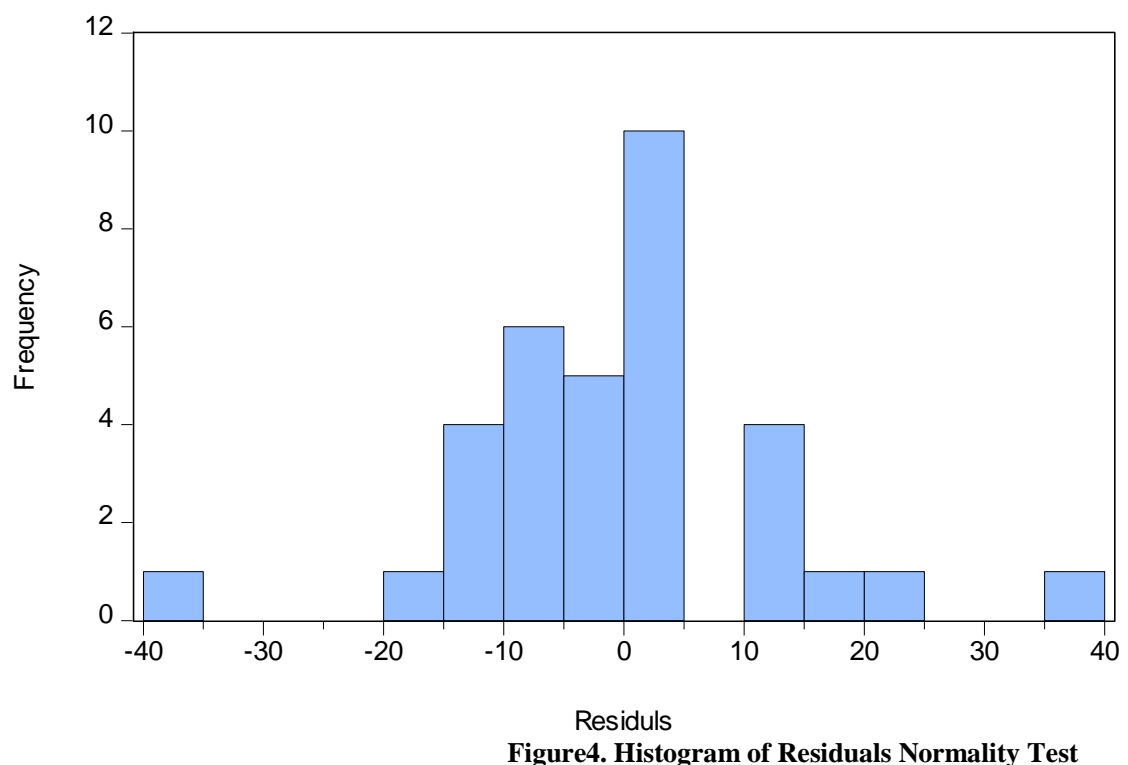

$\begin{array}{lc}\text { Series: Residuals } \\ \text { Sample 1986 } 2019 \\ \text { Observations } 34 \\ \text { Mean } & 1.93 e-15 \\ \text { Median } & -0.447822 \\ \text { Maximum } & 37.60274 \\ \text { Minimum } & -35.20136 \\ \text { Std. Dev. } & 12.86797 \\ \text { Skewness } & 0.328466 \\ \text { Kurtosis } & 4.918559 \\ & \\ \text { Jarque-Bera } & 5.825936 \\ \text { Probability } & 0.054314\end{array}$

Figure4. Histogram of Residuals Normality Test

The result of the test of normality in Figure 4 indicates that we accept the hypothesis of normal distribution of the model error term at the $10 \%$ level. Hence, we conclude that the regression model specification in Equation (4) is adequate.

Table 7. Regression Estimates of Equation (5)

\begin{tabular}{|c|c|c|c|c|}
\hline \multicolumn{3}{|c|}{ Dependent Variable: INF Volatility } & & \\
\hline \multicolumn{5}{|c|}{ Method: ML ARCH - Generalized error distribution (GED) (BFGS / Marquardt steps) } \\
\hline \multicolumn{3}{|c|}{ Sample: 19852019} & & \\
\hline \multicolumn{3}{|c|}{ Included observations: 35} & & \\
\hline \multicolumn{5}{|c|}{ Coefficient covariance computed using outer product of gradients } \\
\hline \multicolumn{5}{|c|}{ Presample variance: backcast (parameter $=0.7)$} \\
\hline \multicolumn{5}{|c|}{$\mathrm{GARCH}=\mathrm{C}(2)+\mathrm{C}(3) * \mathrm{RESID}(-1)^{\wedge} 2+\mathrm{C}(4) * \mathrm{CPS}+\mathrm{C}(5) * \mathrm{M} 1+\mathrm{C}(6) * \mathrm{M} 2+\mathrm{C}(7) * \mathrm{NCG}+\mathrm{C}(8) * \mathrm{NDC}$} \\
\hline Variable & Coefficient & Std. Error & Z-Statistic & Prob. \\
\hline \multirow[t]{2}{*}{$\mathrm{C}$} & 11.99998 & 0.046838 & 256.2013 & 0.0000 \\
\hline & \multicolumn{2}{|c|}{ Variance Equation } & & \\
\hline $\mathrm{C}$ & 38.20624 & 41.97437 & 0.910228 & 0.3627 \\
\hline$\varepsilon_{t-1}^{2}$ & 2.391478 & 2.867654 & 0.833949 & 0.4043 \\
\hline CPS & -2.873133 & 2.938685 & -0.977693 & 0.3282 \\
\hline M1 & 0.184975 & 4.240435 & 0.043622 & 0.9652 \\
\hline M2 & 3.566392 & 4.947609 & 0.720831 & 0.4710 \\
\hline $\mathrm{NCG}$ & -0.020308 & 0.015805 & -1.284955 & 0.1988 \\
\hline NDC & 0.271139 & 0.896773 & 0.302349 & 0.7624 \\
\hline GED PARAMETER & 0.509676 & 0.184778 & 2.758318 & 0.0058 \\
\hline R-squared & -0.162263 & \multicolumn{2}{|c|}{ Mean dependent var } & 19.42322 \\
\hline Adjusted R-squared & -0.162263 & \multicolumn{2}{|c|}{ S.D. dependent var } & 18.69728 \\
\hline S.E. of regression & 20.15722 & \multicolumn{2}{|c|}{ Akaike info criterion } & 7.464767 \\
\hline Sum squared resid & 13814.66 & \multicolumn{2}{|c|}{ Schwarz criterion } & 7.864713 \\
\hline Log likelihood & -121.6334 & \multicolumn{2}{|c|}{ Hannan-Quinn criter. } & 7.602828 \\
\hline Durbin-Watson stat & 0.664936 & & & \\
\hline
\end{tabular}


Amaefula $C$. G. Effects of some monetary policy targets on inflation and inflation volatility: evidence from Nigeria.

The result in Table 7 shows that the monetary policy targets (narrow money supply (M1), broad money supply (M2), net domestic credit(NDC), net credit to government(NCG) and credit to private sector(CPS) ) have no significant effect on inflation volatility.

\begin{tabular}{|l|l|l|l|}
\hline \multicolumn{4}{|c|}{ Table 8. Heteroskedasticity Test: ARCH } \\
\hline F-statistic & 0.091048 & Prob. F(16,2) & 0.9990 \\
\hline Obs*R-squared & 8.007051 & Prob. Chi-Square(16) & 0.9487 \\
\hline
\end{tabular}

The result in Table 8 , shows there is no heteroskedasticity in the model residuals as the p-values are not significant under 5\% level. Hence, there is no ARCH effect.

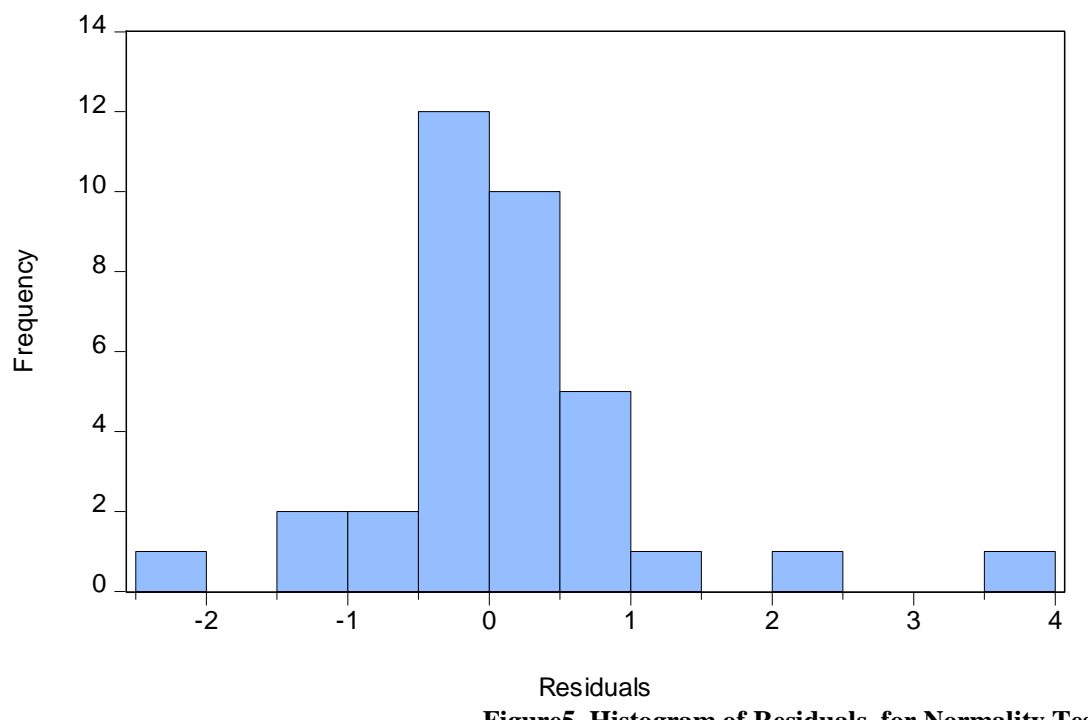

$\begin{array}{ll}\text { Series: Standardized Residuals } \\ \text { Sample 1985 } 2019 \\ \text { Observations } 35 \\ \text { Mean } & 0.118305 \\ \text { Median } & 2.68 \mathrm{e}-06 \\ \text { Maximum } & 3.653257 \\ \text { Minimum } & -2.269160 \\ \text { Std. Dev. } & 0.980991 \\ \text { Skewness } & 1.100695 \\ \text { Kurtosis } & 7.150204 \\ & \\ \text { Jarque-Bera } & 32.18587 \\ \text { Probability } & 0.000000\end{array}$

Figure5. Histogram of Residuals for Normality Test

The result of the test of normality in Figure 5 indicates that the $p$-value of the Jarque-Bera test is significant under 5\% level hence, we accept the hypothesis of normal distribution of the model error term. Consequently, the regression model specification in Equation (5) is adequate.

\subsection{DISCUSSION OF RESULTS}

The result in Table 4 showed that the monetary policy target variables (narrow money supply (M1), broad money supply(M2), net domestic credit(NDC), net credit to government(NCG) and credit to private sector(CPS) ) have no significant effect on inflation except that of M2 and it is significant at 5\% level. This implies that amongst all the monetary policy targets, only M2 is sensitive to inflation and this sensitivity spurs inflation instead of curbing it. How? The empirical outcome of the analysis in Table 4 showed that a unit rise in M2 will result to about 3.57 units rise in inflation. If $\mathrm{M} 2$ is targeted to control inflation, the effect should be negative. And if M2 is targeted to control deflation, its effect should be positive.

The result in Table 5 revealed that the monetary policy targets under study have no significant effect on the volatility of inflation. The finding is related to that of ${ }^{[4]}$ who opined that monetary policy rate (MPR) such as one month deposit rate is not proactive enough to curb the rising inflationary pressure in Nigeria.

However, the findings of the study could not be related to previous study due to the fact that there is little or no past study that focused on the exogenous variables used in the present study.

\section{CONCLUSION}

There is no doubt that the narrow money supply (M1), broad money supply(M2), net domestic credit(NDC), net credit to government(NCG) and credit to private sector(CPS) are targeted to curb inflationary pressure so as to attain price stability in Nigeria's economic space. However, the findings showed that monetary policy targets are neither sensitive 
Amaefula $C$. G. Effects of some monetary policy targets on inflation and inflation volatility: evidence from Nigeria.

to inflation nor inflation volatility except M2 that significantly enhanced inflation instead of decreasing it.

Hence, it becomes imperative for the government, especially the CBN Monetary policy Committee (MPC) to make proactive policies targeted to reduce inflationary pressures so as to attain price stability in Nigeria.

\section{Acknowledgement: None}

\section{Conflict of Interest: None}

\section{Source of Funding: None}

\section{REFERENCES}

1. Akoto D. The Relationship between Interest Rates and Inflation in Ghana and Their Impact on Economic Growth for the Period 2006-2019. Journal of Finance and Economics, 2021, 9(1): 3441.

2. Amaefula C. G. The Effects of Inflation and its Risk on Interest Rate: An Empirical Evidence from Nigeria. Economy, 2016a, 3(2): 74-78.

3. Amaefula C. G. Long-Run Relationship between Interest Rate and Inflation: Evidence from Nigeria. IOSR Journal of Economics and Finance. 2016b, 7(3): 24-28.

4. Amaefula C. G. Does monetary policy curb inflation in Nigeria? An empirical support. International Journal of Research in Economics and Social Sciences (IJRESS), 2017, Vol.7(10): $563-572$.

5. Asso, P.F., Kahn, G.A. and Lesson, R. The Taylor rule and the practice of central banking. The Federal Reserve Bank of Kansas City, Economic Research Department, Research Working Papers, RWP. 2010, No 10-05: 1-52.

6. Berument $\mathrm{H}$. The impact of inflation uncertainty on interest rates in the UK. Scottish Journal of Political Economy, 1999, 46(2): 207- 218.
7. Bollerslev, Tim. Generalized Autoregressive Conditional Heteroskedasticity, Journal of Econometrics, 1986, 31: 307-327.

8. Central Bank of Nigeria. Monetary policy review, 2020. Available from www.cbn.gov.ng.

9. Chan L.K.C. Consumption, inflation risk, and real interest rate: An empirical analysis. Journal of Business,1994, 67(1): 69-96.

10. Dickey DA, Fuller WA. Distribution of the Estimators for Autoregressive Time Series with a unit root, Journal of the American Statistical Association. 1979; 74: 427-431.

11. Engle, Robert F. Autoregressive Conditional Heteroskedasticity with Estimates of the Variance of U.K. Inflation, Econometrica, 1982, 50: 9871008.

12. Fama $\mathrm{E}$ and Gibbons $\mathrm{M}$. Inflation, real returns and capital investment. Journal of Monetary Economics, 1982, 9(3): 297-323.

13. Fama E and Schwert G. Asset returns and inflation. Journal of Financial Economics, 1977, 5(2): 115-146.

14. Fave $P$ and Auray S. Interest rate and inflation in Monetary models with ingenious money growth rate, Economic Bulletin, 2002, 5(1): 1-10.

15. Gul E and Ekinci A. The causal relationship between nominal interest rate and inflation: The case of Turkey. Scientific Journal of Administrative Development, 2002, 4(21): 54-69.

16. Herwartz H. and Reimers H. Modelling the fisher hypothesis: World wide evidence. German Economic Review, 2006, 7(1): 65-86.

17. Kugler $P$. The dynamic relationship between interest rates and inflation: An empirical investigation. Empirical Economics, 1982, 7(1): 25-137.

18. Mishkin F.S. The real interest rate. An empirical investigation. CarnegieRochester Conference Series on Public Policy, 1981, 15(1): 151-200. 
Amaefula $C$. G. Effects of some monetary policy targets on inflation and inflation volatility: evidence from Nigeria.

19. Umoru D and Oseme S.A. Inflation expectations and interest rate variation in Nigeria: An econometric assessment of the evidence. International Journal of Development and Economic Sustainability, 2013, 1(2): 1-12.

20. Woodford, M. The Taylor rule and optimal monetary policy. The American
Economic Review, 2001, 91(2), 232237.

How to cite this article: Amaefula C. G. Effects of some monetary policy targets on inflation and inflation volatility: evidence from Nigeria. International Journal of Research and Review. 2021; 8(5): 412-422. DOI:https://doi.org/10.52403/ijrr.20210551 